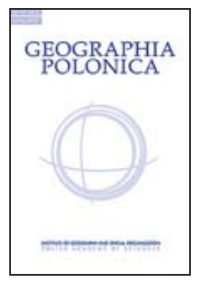

\title{
THE LOCALIZATION OF URBAN HEAT ISLAND IN THE KATOWICE CONURBATION (POLAND) USING THE COMBINATION OF LAND SURFACE TEMPERATURE, NORMALIZED DIFFERENCE VEGETATION INDEX AND NORMALIZED DIFFERENCE BUILT-UP INDEX
}

\author{
Ádám Nádudvari (i) \\ Faculty of Natural Sciences \\ University of Silesia \\ Będzińska 60, 41-200 Sosnowiec: Poland \\ e-mail: adam.nadudvari@us.edu.pl
}

\begin{abstract}
The localization of Surface Urban Heat Island (SUHI) as a potential heat risk for the urban population was evaluated. The paper aimed to propose an approach to quantify and localize (SUHI) based on Landsat series TM, ETM+, OLI satellite imageries from the period 1996-2018 and recognize the Atmospheric Urban Heat Island (AUHI) effects from long term temperature measurements. Using the theoretical relation between the Normalized Difference Built-up Index (NDBI), the Normalized Difference Vegetation Index (NDVI) and the

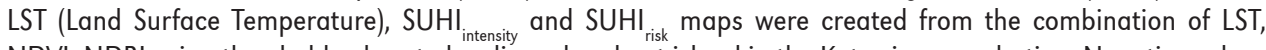
$\mathrm{NDVI}, \mathrm{NDBI}$ using threshold values to localize urban heat island in the Katowice conurbation. Negative values of SUHI intensity characterize areas where there is no vegetation, highly built-up areas, and areas with high surface temperatures. The urban grow - revealed from SUHI - and global climate change are acting together to strengthen the global AUHI effect in the region as the temperature measurements were indicated.
\end{abstract}

\section{Key words}

NDVI • NDBI • Land Surface Temperature (LST) - Surface Urban Heat Island (SUHI)

\section{Introduction}

It is well documented that urbanization has a significant effect on local weather and climate. As a result of urbanization, an urban heat island $(\mathrm{UHI})$, an unplanned change of local climate can be formed (Landsberg,
1981; Streutker, 2002; Lu et al., 2009). Greater urbanization and densely built-up areas lead to more intensive UHI, as the lower albedo and higher degree of sealing of urban areas significantly alter the surface energy budget, causing marked temperature differences between urban and rural areas. 
In this context, it is important to note the difference between "atmospheric UHI (AUHI)", the occurrence of higher air temperature in urbanized areas than in surrounding areas and "surface UHI (SUHI)", the occurrence of higher surface temperature in urbanized areas than in surrounding areas (Katsoulis \& Theoharatos, 1985; Oke, 1987, 1988; Wang et al., 1990; Camilloni \& Barros, 1997; Du et al., 2014; Kuchcik et al., 2014; Kuang et al., 2015; Majkowska et al., 2017; Kaplan et al., 2018). In Poland, during climate change, the occurrence of the AUHI or SUHI is the most important and problematic feature of urbanized areas. In Polish climatic conditions, the formation of $\mathrm{AUHI}$ is related to weather types connected with atmospheric fronts and summer nights where AUHI reaches higher intensity (Kłysik \& Fortuniak, 1999). The AUHI in cities like Kraków can be more intense compared to other polish cities situated on relatively flat area i.e. Wrocław or Łódź. That phenomenon caused by the location of Kraków in the Vistula River valley where the katabatic flows do not enter the city interior. In the rural areas around the city, the cold air reservoirs are formed, and additionally, the sensible heat flux is significantly limited there due to the evaporation of the river waters (Bokwa, 2011). Increased land-surface temperatures caused by the SUHI effect during rapid urbanization or extension of builtup areas have a profound impact on local weather by altering local wind patterns (city structure), promoting the development of clouds and fog, increasing the number of lightning events and influencing the rates of precipitation (Oleson et al., 2001; Hung et al., 2006; Chen et al., 2009; Imhoff et al., 2010; Liu \& Zhang, 2011; U.S. EPA, 2014a,b; Yang et al., 2016).

There is a theoretical relation between LST (Land Surface Temperature), the normalized difference vegetation index (NDVI) and the normalized difference built-up index (NDBI) (Qin et al., 2001; Liu \& Zhang, 2011; Alfraihat et al., 2016; Kaplan et al., 2018; Gazi \& Mondal, 2018). High NDVI values (ranges from -1 to 1) apply to, e.g., parks and low NDBI (ranges from -1 to 1) values with lower surface temperatures to vegetation-covered areas. Water bodies have low $\mathrm{NDVI}<0$ as well as relatively low surface temperatures (during a day) and low NDBI. Built-up areas (and bare soils) have high NDBI, low NDVI, and high surface-temperature values (Alfraihat et al., 2016; Kaplan et al., 2018). These indices can help to show the impact of green- and build-up areas on the urban heat island. The NDBI index underpins an effective technique to map builtup areas as it uses the reflectivity of buildings which is higher in the short-wave infrared band (SWIR1) and lower in the near-infrared band (NIR) (Qin et al., 2001; Alfraihat et al., 2016). Therefore, $N D V I=(N I R-R) /(N I R+R)$ and $N D B I=(N I R-S W I R 1) /(N I R+S W I R 1)$ were calculated with NIR, R (visible red bands), and SWIR.

The study area (Katowice conurbation, Poland) is an excellent place to review SUHI effects because each city in the conurbation has its own densely built-up areas. The research aimed to develop a SUHI intensity-related index (the combination of LST, NDBI, NDVI), a SUHI risk and applying these indexes to localize the potential surface urban heat islands based on threshold values. As SUHI, AUHI is related to each other and appears together within a city, the other aim was to calculate temperature duration curves - using archive temperature measurement data - to recognize the AUHI effect in the Katowice conurbation. Usually, SUHI appears within the parts of the city with a small percent of vegetation, where densely built-up areas are accompanied by high surface temperature anomalies (called heat emitters) e.g. Abegunde and Adedeji (2015), Tarawally et al. (2018) or Fashae et al. (2020). Concerning e.g. the research of Zaeemdar and Baycan (2017) who analyzed the spatial pattern (using Landsat $8 \mathrm{OLI}$ ) of LST, surface albedo, NDVI, and land use/land cover in Istanbul, Turkey where artificial surfaces with low albedo and low vegetation cover have the most positive exponential relationship with LST and an increasing effect on SUHI formation. 


\section{Upper Silesian conurbation}

The present study is related to surface SUHI formation in the Katowice conurbation, also known as the Upper Silesian- or Silesian conurbation (Fig. 1A, B). It was established in the 1800 s as one of the largest mining and industrial regions in Europe covering $3213 \mathrm{~km}^{2}$ and with a population in 2013 of 2.468 million. In Central Europe, it is the second-largest urban area after Berlin. The conurbation consists of 33 cities, including the core cities of Katowice, Gliwice, Sosnowiec, Bytom, and Tychy (Krzysztofik et al., 2011). This significant commercial- and the industrialized area is based on coal mining, steel production, the mining and processing of $\mathrm{Pb}-\mathrm{Zn}$ ores, coke, and textile manufacture. Between 19451989, the industrial potential of the region increased significantly. Coal mining together with other coal-based industries, i.e., iron and energy expanded (Tkocz, 2005; Spórna et al., 2016). The heavy industrialization, dense traffic, coal-burning by domestic furnaces resulting poor air quality (especially during the heating season or during summertime when wind speed is low and air-temperature is hot); the concentration of small particulate matter exceeds both daily-and yearly admissible levels (Fig. 1A, B - the air-quality data has been calculated from hourly measurements and converted to daily data for PM10). During

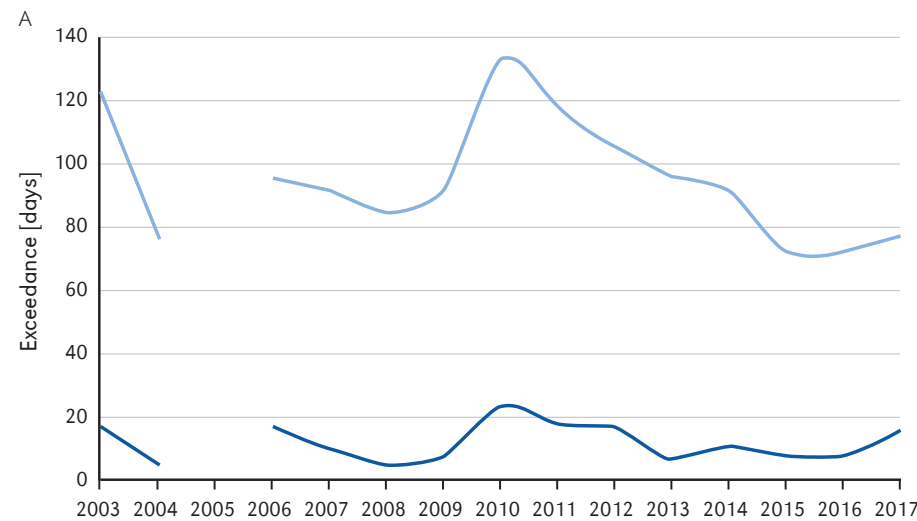

B

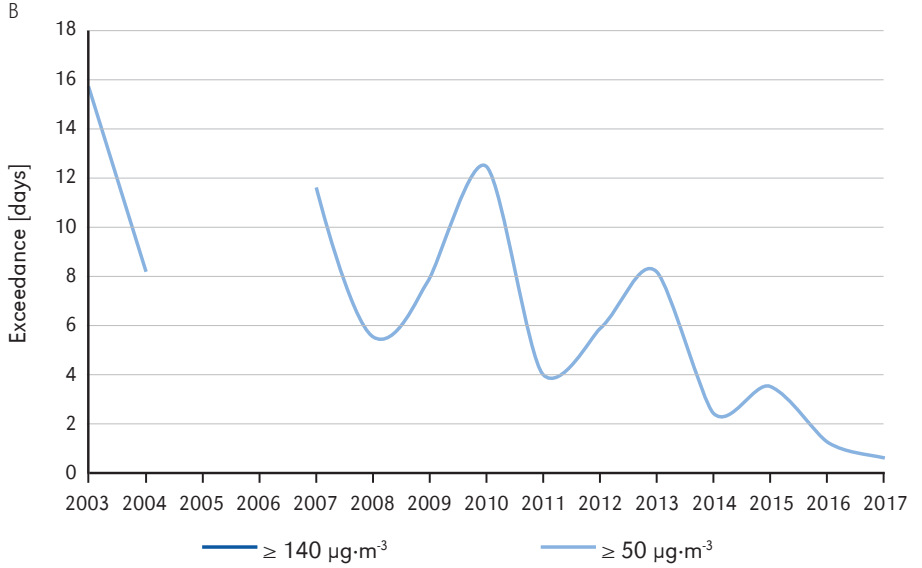

Figure 1. Number of days with different PM10 levels yearly (A) and during the summer season (B) in Katowice

Source of data: http://powietrze.gios.gov.pl/pjp/archives 
the analyzed period (2003-2017), the yearly PM10 concentrations reached or exceeded $50 \mu \mathrm{g} / \mathrm{m}^{3}$ on $\sim 80-120$ days and $140 \mu \mathrm{g} / \mathrm{m}^{3}$ on $\sim 5-20$ days every year. Even in summer, PM10 values can exceed $50 \mu \mathrm{g} / \mathrm{m}^{3}$ on some days (Fig. 1B). The bad air quality is related to coal combustion (domestic) and processing, heavy industry, biomass combustion and intense traffic (Rogula-Kozłowska et al., 2011; Zaciera et al., 2012; Klejnowski et al., 2012). Usually, an unwanted effect of UHIs is the poor air quality caused by windless and cloudless conditions, especially during summertime. The cooling effect of the wind helps to eliminate the adverse effects of heat island on the micro-climate, human thermal comfort, and keep clean the air over an urbanized area (Rajagopalan et al., 2014). Furthermore, poor air quality can affect the urban quality of life and impact on human health by, e.g., aggravating asthma and causing heat-related illnesses and fatalities (Oleson et al., 2001; Liu \& Zhang, 2011; Weng, 2012; U.S. EPA, 2014b; Aslan \& Koc-San, 2016).

\section{Methodology}

Long-term air-quality analysis carried out at the IETU-Katowice air-quality monitoring station (GPS coordinates of the station: N: 50.264611; E: 18.975028, address: 6. Kossutha Street, Katowice). Source of raw data: http://powietrze.gios.gov.pl/pjp/archives. To obtain precise data for built-up areas, Sentinel 1 SLC data (5 images from different paths) taken from https://scihub.copernicus. eu/ were used and processed with SNAP 5.0 software. Using the average coherence and intensity $\mathrm{V} \vee$, the $\mathrm{VH}$ polarization of 5 images was analyzed where low backscatter and high coherence values correspond to bare surfaces such as agricultural areas and lakes, whereas high coherence values and high backscatter values relate to built-up areas. The created RGB image (Red - the average intensity of $\mathrm{VH}$, Green - the average intensity of $\mathrm{V} V$, Blue - average coherence) was analyzed, using reference samples (road, water, coal-waste dump, agriculture areas, bare soils, forests, built-up areas) and the image was classified using a maximum likelihood classification. However, these data were prepared only for Figure 2 as a representative form of urban footprint in the region.

Seven Landsat images were chosen from 1996-2017 (Tab.). The image data were collected from https://earthexplorer.usgs.gov/ with zero clouds, haze, and fog cover in the summertime or at the end of spring or the beginning of autumn when there were fullgrowth vegetation and a higher risk of UHI formation. The first step in the determination of SUHI was to obtain the LST of Landsat

Table. The details of used satellite images

\begin{tabular}{|c|c|c|c|c|c|c|}
\hline No. & $\begin{array}{c}\text { Data } \\
\text { acquired }\end{array}$ & $\begin{array}{c}\text { Scene center } \\
\text { time }\end{array}$ & Scene ID & $\begin{array}{l}\text { Satellite } \\
\text { type }\end{array}$ & $\begin{array}{l}\text { TIR band } \\
\text { resolution } \\
\text { [meters] }\end{array}$ & $\begin{array}{c}\text { Used TIR } \\
\text { bands + central } \\
\text { wavelengths }[\mu \mathrm{m}]\end{array}$ \\
\hline 1. & 23.07.1996 & $08: 47: 16$ & LT51880251996205FUI00 & Landsat 5 & 120 & Band $6(11.45)$ \\
\hline 2. & 09.08.1999 & $09: 25: 21$ & LE71880251999221SGS01 & Landsat 7 & 60 & Band $6(11.45)$ \\
\hline 3. & 29.07.2013 & $09: 40: 37$ & LC81890252013210LGN02 & Landsat 8 & 100 & Band $10(10.8)$ \\
\hline 4. & 16.09 .2016 & $09: 32: 40$ & LC81880252016260LGN01 & Landsat 8 & 100 & Band $10(10.8)$ \\
\hline 5. & 30.05 .2017 & 09:32:02 & LC81880252017150LGN01 & Landsat 8 & 100 & Band 10 (10.8) \\
\hline 6. & 22.06 .2017 & $09: 38: 22$ & LC81890252017173LGN00 & Landsat 8 & 100 & Band $10(10.8)$ \\
\hline 7. & 18.08 .2017 & $09: 32: 30$ & LC81880252017230LGN00 & Landsat 8 & 100 & Band $10(10.8)$ \\
\hline 8. & 06.05 .2018 & $20: 30: 55$ & $\begin{array}{l}\text { AST_ } \\
\text { L1T_00305062018203055_ } \\
\text { 20180507125429_6121 }\end{array}$ & $\begin{array}{l}\text { ASTER TIR } \\
\text { (nighttime) }\end{array}$ & 90 & \\
\hline
\end{tabular}




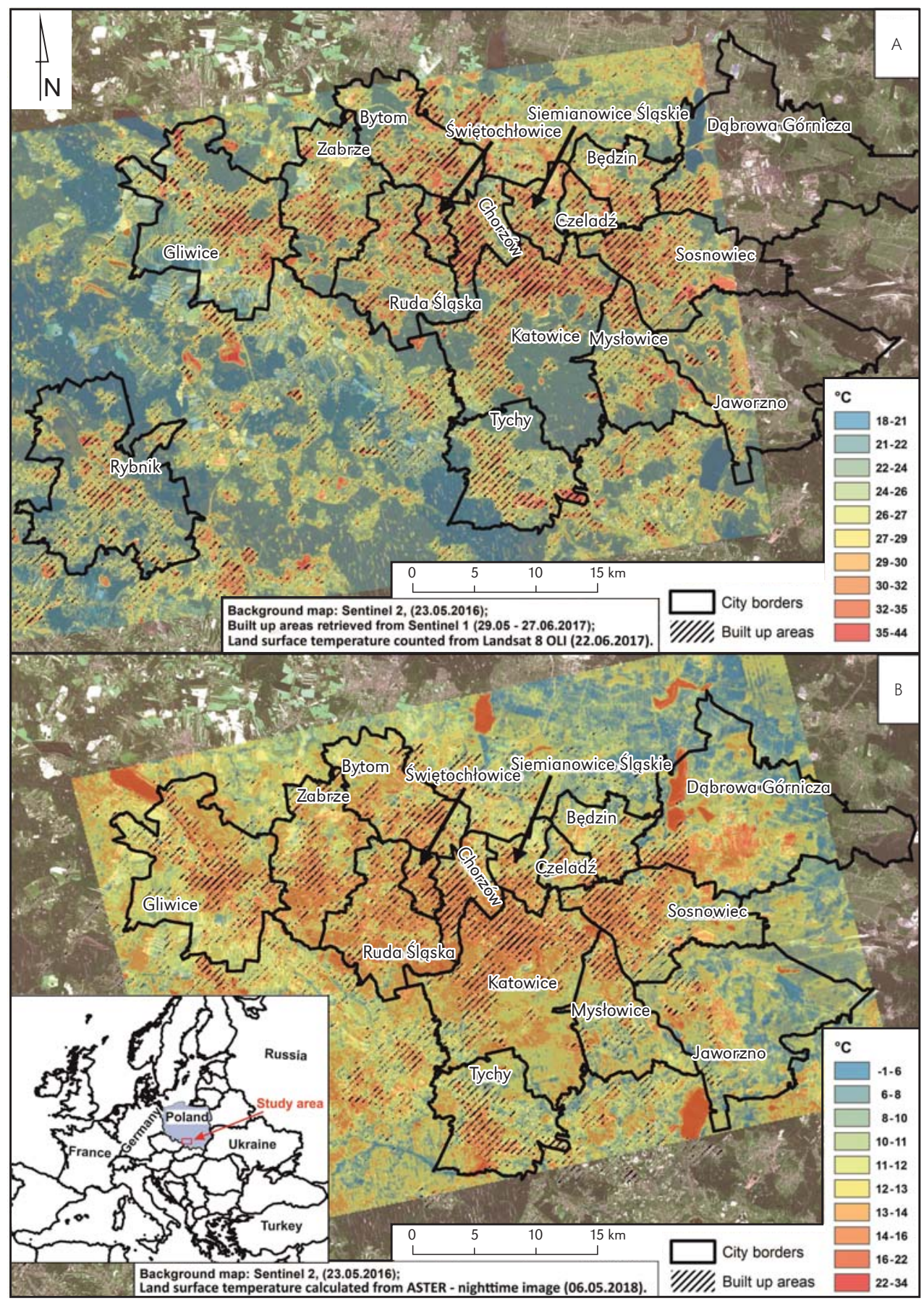

Figure 2. LST calculated for Landsat 8 OLI and ASTER (night-time) images combined with built-up areas retrieved from Sentinel 1 images 
(4-5TM, 7 ETM+, 8 OLI) and ASTER satellite images (using thermal infrared bands (TIRS). The calculations were conducted according to https://www.usgs.gov/land-resources/ nli/landsat/using-usgs-landsat-level-1-dataproduct. First, the radiance was calculated and then the brightness temperature was converted from Kelvin to Celsius according to $T_{\text {Celsius }}=T_{\text {Kelvin }}-273.15$ ( $T S=$ temperature at Satellite). To obtain the LST, the thermal emissivity map first had to be generated based on the spectral absorption properties of the surface materials as surface temperatures are directly related to surface physical properties:

Proportion of vegetation

$$
\begin{aligned}
(P V)= & ((N D V I-N D V I m i n) /(N D V I m a x \\
& -N D V I m i n))^{2}
\end{aligned}
$$

where:

NDVImin and NDVImax max = minimum- and maximum values of NDVI image (helped to separate the surface materials).

Then, thermal emissivity (e) was calculated as follows:

Emissivity $(e)=0.004 \mathrm{Pv}+0.986$

where:

$\mathrm{Pv}=$ Proportion of vegetation

Land Surface Temperature (LST) was calculated as follows:

$$
\mathrm{LST}=\mathrm{TS} /\left[1+\left(\mathrm{DN}_{\mathrm{TIR}} \cdot \mathrm{TS} / \mathrm{p}\right) \cdot \ln (e)\right]
$$

using the thermal (e) and (TS) values proposed by Weng et al. (2004), Jiménez-Muñoz et al. (2009) and Suresh et al. (2016)

where:

$\mathrm{TS}=$ temperature at satellite;

$\mathrm{DN}_{\text {TIR }}=\mathrm{DN}$ values of the original thermal band of Landsat image used and

$P=1.438 \cdot 10^{-2} \mathrm{mK}=14,388 \mu \mathrm{m} \mathrm{K}$;

$P$ was calculated according to $P=h \cdot C / S$

$h=$ Planck's Constant (6.626.10 $\left.{ }^{-34} \mathrm{~J} \mathrm{~s}\right)$;

$\mathrm{C}=2.998 .108 \mathrm{~m} / \mathrm{s}$, i.e., the velocity of light;

$S=1.38 \cdot 10^{-23} \mathrm{~J} / \mathrm{K}$, i.e., Boltzmann Constant.

All calculations were performed in ENVI 5.3 software.

\section{Calculating urban heat islands and risk}

The combining of LST with NDVI, NDBI may help to identify those areas where SUHIs can form with different heat emissions (termed "SUHI ${ }_{\text {intensity }}$ "), e.g., where there are high surface temperatures due to lack of vegetation or builtup areas like city centers with hot roofs; these which will tend to be characterized by the highest SUHI intensities. The map was calculated according to (proposed by the Author):

$\mathrm{SUHI}_{\text {intensity }}=((\mathrm{NDBI}+\mathrm{NDVI}) /(\mathrm{NDBI}+\mathrm{LST}) /$

$(N D V I+L S T)) \cdot 1000$

To select those areas where heat emitters (densely built-up areas, building that transmitting thermal energy across the surface into the atmosphere) are located, the SUHI ${ }_{\text {intensity }}$ map was reworked using as reference areas, the (mixed forest) code 313 from Corine Land Cover (CLC 2018) for forested areas and, for built-up urban areas, codes 111 (continuous urban), 112 (discontinuous urban), 121 (industrial- and commercial) and 122 (roadand railroad). Such reference areas were marked separately for each city on each Landsat image used. The Corine Land Cover (CLC 2018) was obtained from http://clc. gios.gov.pl. According to Martin et al. (2015) and Du et al. (2014), choosing an urban core reference area (hot surface component) and an external thermal reference (cold surface component), i.e., forested area aided the development of thresholds above the spatial average. Later, the $\mathrm{SUHI}_{\text {intensity }}$ image was extracted using the CLC 2018 codes for builtup areas. Then, threshold values were developed for each extracted image and for each city to select the SUHI according to the following formula (proposed by the Author):

$\mathrm{SUHI}_{\text {threshold value }}=(($ meanBUA - meanFRA $) /$

$\left(\right.$ meanCCR - meanFRA)).STDEV ${ }_{\text {BUA }}$

where:

meanBUA - mean value of Built-Up Areas according to CLC 2018;

meanFRA - mean value of the Forested Reference Area; 
meanCCR - mean value of the City Center Reference area and

STDEV $_{\text {BUA }}$-Standard Deviation of built-up areas according to CLC 2018.

A further localization and classification

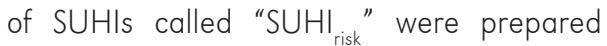
based on the LST image using the reference areas (forest, city center) mentioned above. The image classification was carried out according to the following formula (proposed by the Author):

$$
\begin{aligned}
& \text { SUHI } I_{\text {risk }}=\left(\left(L S T-\text { meanFRA }_{\text {Cels. }}\right) /\left(\text { meanCCR }_{\text {Cels. }}\right. \text { (6) }\right. \\
& \left.\left.- \text { meanFRA }_{\text {Cels. }}\right)\right)^{2}
\end{aligned}
$$

where:

LST is the Land Surface Temperature image; meanFRA $_{\text {Cels. }}$ is the mean value of the Forested Reference Area taken from the LST image in Celsius and

meanCCR $\mathrm{Cels}_{\text {. }}$ is the mean value of City Center Reference area taken from the LST image in Celsius.

The built-up areas were then extracted from the image according to the CLC 2018 codes and the results classified as follows:

- $<0.2$ - no risk;

- 0.2-0.4 - low risk;

- 0.4-0.6 - moderate risk;

-0.6-0.8 - medium risk;

- 0.8-1 - high risk;

- $>1$ - highest risk.

\section{Calculating temperature duration intervals}

The Landsat series cannot give a detailed trend of air-temperature changes (fall rise), therefore a long term (last 44 years) air-temperature data set was used to see how the AUHI influences the local air-temperatures where are different albedos. Only two meteorological stations had long term available air-temperature data in the Katowice conurbation. One called "Planetarium" located in the Silesian Park - Park Ślaski (GPS coordinates of the station: N: 50.290713; E: 18.992605; address: 4. Planetarium alley,
Chorzów), surrounded by trees and the second is in Muchowiec Airport (GPS coordinates of the station: N: 50.240622; E: 19.032693; address: 1 Lotnisko 1, Katowice) - surrounded by meadow and buildings is located by the Katowice - Muchowiec local Airport and by a newly constructed shopping center (Fig. 6). For the temperature duration intervals, daily maximum temperatures representing the warmest part of a day and indicating the greatest extension of SUHI and $\mathrm{AUHI}$ with the highest temperatures were used. Daily maximum temperature data for 1973-2017 was obtained from https://ogimet. com for Muchowiec and from meteorological diaries for 1994-2016 from Chorzów Planetarium. The locations of both sites are shown in Figure 6. The collected data were grouped to construct a frequency distribution in the following way. All observations were divided into five-year intervals. Within each interval, the temperature data were ordered from the highest to the lowest without paying attention to when it was recorded in the given 5 years. The temperature data was also split into $5^{\circ} \mathrm{C}$ intervals. The number of data in each $5^{\circ} \mathrm{C}$ interval is termed as the temperature frequency index $f_{y}(h)$ where $y$ denotes the fiveyear interval and $h$ is the height (the number of data) of each $5^{\circ} \mathrm{C}$ interval. The accumulate frequency is calculated by the formula:

$$
f_{y}(h)=\sum_{k \geq h}^{n} f_{y}(k)
$$

where:

$k$ is the summation index.

The frequency distribution was then calculated by the formula

$$
d_{y}(h)=\frac{f_{y}(h)}{\sum_{k^{\prime}} f(k)} \cdot 100 \%
$$

The frequency distribution tables are presented as temperature duration curves (Fig. 7A, C). 
The frequency index $f(h)$ shows how often in the analyzed period the daily maximum temperatures reached or exceeded the lowest level in a particular category. This cumulative frequency index can equally well be applied to characterize air temperature changes during, e.g., every 5 years.

The frequency index aided comparison of the maximum daily temperatures between 1994-2016 from Muchowiec and Chorzów Planetarium. To construct the exceedance diagram (Fig. $7 \mathrm{E}$ ), $20^{\circ} \mathrm{C}$ was chosen as a fixed point and the range $h_{y}$ max for every five-year interval was checked to ascertain where it fell. The corresponding distribution data over those ranges where the fixed $20^{\circ} \mathrm{C}$ point fell was then calculated according to the formula:

$$
\text { MAX } x_{y}=\sum_{k \geq h_{y}^{\max }}^{n} d_{y}(k)
$$

\section{Results and discussion}

Figure 2 should be considered as an overview where Landsat image representing the morning, the ASTER image the evening state of surface temperatures (see Table - center times). The location of SUHIs in the conurbation at different parts of the day is shown in Figure 2A for daytime- and Figure 2B for night-time heat islands. Commonly, densely built-up areas, industrial areas, and bare coal-waste dumps are hot areas with temperatures of $10-12^{\circ} \mathrm{C}$. Agricultural areas are $6-7^{\circ} \mathrm{C}$ warmer than forest and water bodies. According to Kim (1992), inner-city temperatures can be $10^{\circ} \mathrm{C}$ higher than those of nearby woodlands. Similar trends were reported for Polish cities like Kraków by Lewinska et al. (1982) or Bokwa (2011), from Wroclaw by Szymanowski (2004) or from Łódź by Fortuniak (2003). Water bodies are visible as heat emitters in the night-time satellite image, even warmer $\left(4^{\circ} \mathrm{C}\right)$ then the densely built-up areas. The forested areas are also warmer $\left(5-6^{\circ} \mathrm{C}\right)$ when compared to, e.g., agricultural areas (Fig. 2B - northern part) or river valleys. In case of Łódź AUHI developed in the middle of the night with the greatest occurrence in the summertime (June-August) with $3-4^{\circ} \mathrm{C}$, and sometimes even $6^{\circ} \mathrm{C}$ warmer than the surrounding areas (Kłysik \& Fortuniak, 1999; Wilk, 2015). Similarly to Łódź in Białystok, the development of the AUHI starts in the afternoon and, reaching maximum in the late-evening hours (Czubaszek \& Wysocka-Czubaszek, 2016).

The calculated SUHI risk' $_{\text {SUHI }}$ intensity, and population density for various cities of the conurbation are shown in Figure 3. Data for population density (resolution 100 meters) taken from https://www.eea.europa.eu/ data-and-maps/data/population-density-disaggregated-with-corine-land-cover-2000-2. The location of used reference areas in the formulas (5), (6) namely: meanBUA - built-up areas and meanFRA - forested areas) see on Fig. 3. Threshold values of SUHI ${ }_{\text {intensity }}$ were for Katowice: 0.35; Bytom: 0.37; Gliwice: 0.35; Sosnowiec: 0.34 according to formula (5), the pixel values were considered under the threshold values. Negative values of SUHI tensity indicative of a potential SUHI location can be observed in areas with no vegetation, highly built-up areas and high LST. Furthermore, the combined image with a resolution of 30 meters can provide more detailed information concerning, e.g., roads or the shapes of hot roofs as hot surfaces, and SUHI vary within built-up areas (Fig. 3A,B). Generally, areas with the highest risk of SUHI formation occur in densely built-up areas, i.e., city centers with higher population see by Katowice, Bytom and Gliwice, industry- or logistic parks and shopping centers. The formation of stronger and size of $\mathrm{AUHI}$ or SUHI is depended not only on the total area of the city but also on the degree of compactness of building development in city center i.e. a high percentage of artificial surfaces, very narrow streets in a few square kilometers as it showed by Kłysik \& Fortuniak (1999) in Łódź or Warsaw by Błażejczyk et al. (2016). That is well agreed with the formation of SUHIs 


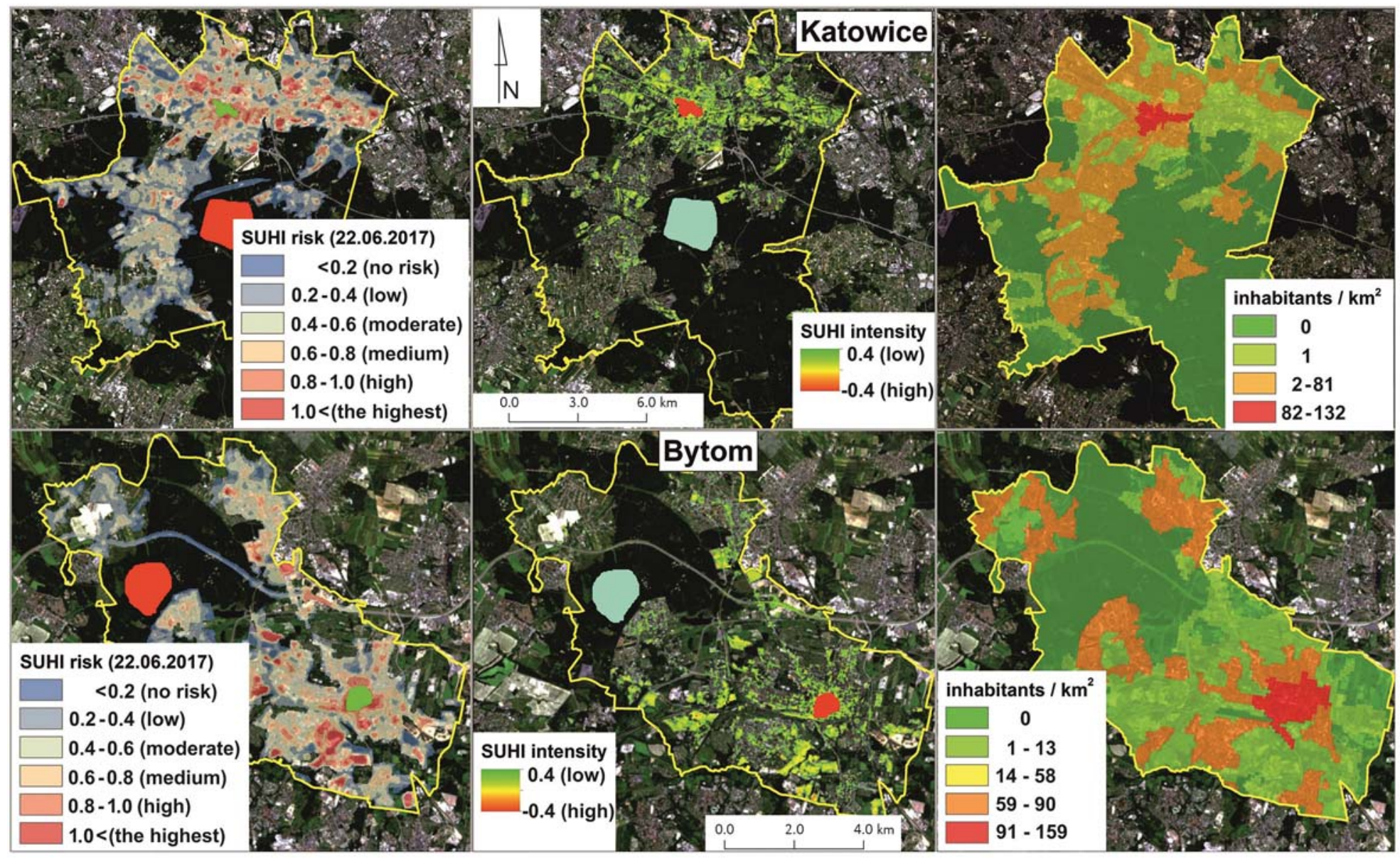

Figure 3A. Representative SUHI ${ }_{\text {risk }}$ and SUHI ${ }_{\text {intensity }}$ for Katowice and Bytom - cities from the Katowice conurbation

Source of data for population density: https://www.eea.europa.eu/data-and-maps/data/population-density-disaggregated-with-corine-land-cover-2000-2 


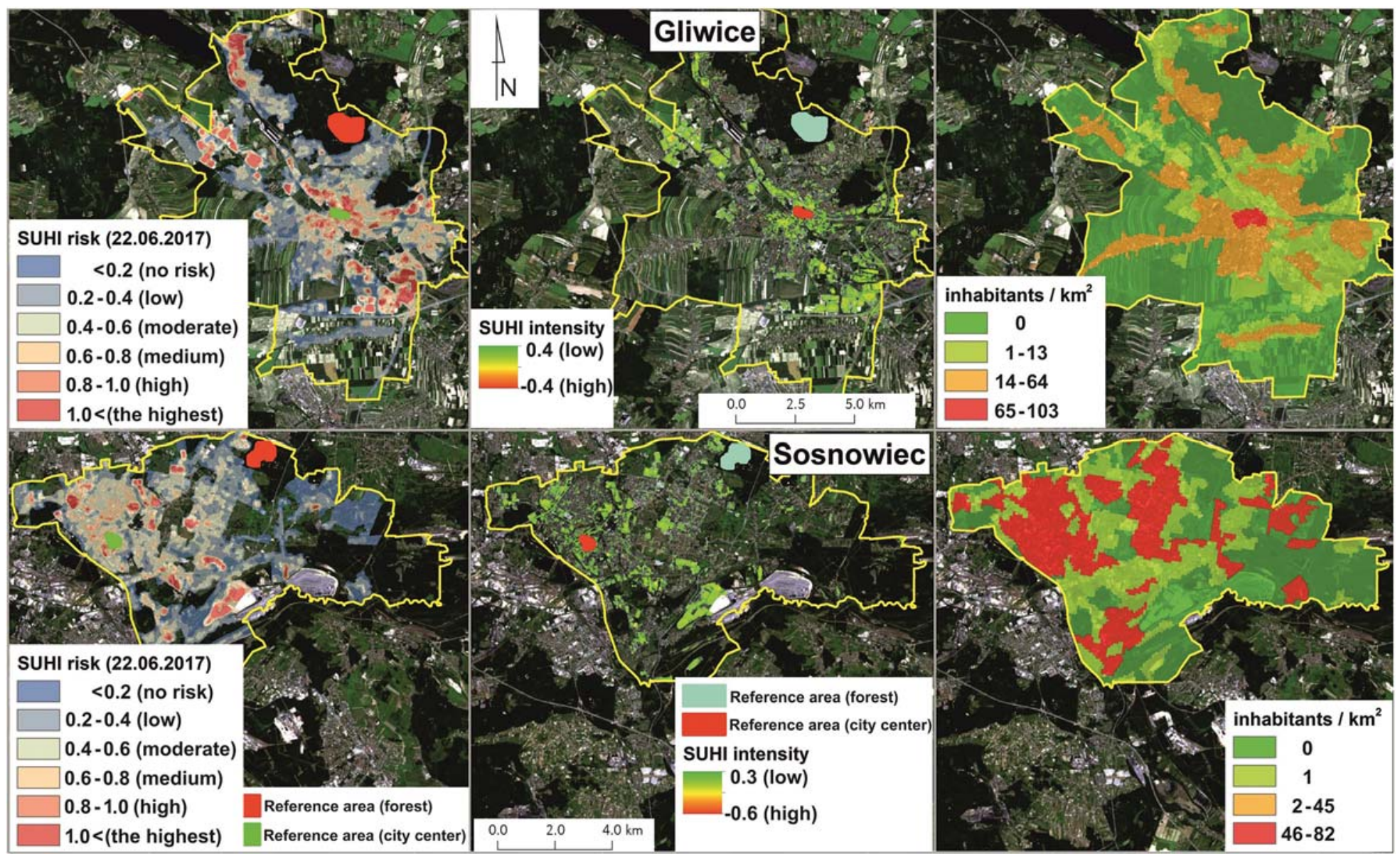

Figure 3B. Representative SUHI risk $_{\text {and }}$ an $U \mathrm{H}_{\text {intensity }}$ for Gliwice and Sosnowiec - cities from the Katowice conurbation

Source of data for population density: https://www.eea.europa.eu/data-and-maps/data/population-density-disaggregated-with-corine-land-cover-2000-2 
appearance in Bytom or Katowice where the structure of the city centers are similarly compacted as in Łódź. In the case of Sosnowiec the SUHI appearing separately and less concentrated to those areas where a dense population is (Fig. 3A,B). Therefore in the case of Katowice conurbation concerning the climate change effects, it is crucial to localize the SUHIs based on satellite images. The formation of $\mathrm{AUHI}$ or SUHI can promote the exposure of health risks within these densely built-up areas cconcerning the population density. Dong et al. (2014) well demonstrated a spatial-temporal pattern of higher health risk caused by UHI in urban areas, lower risk in the borderland between urban- and rural areas, and lowest risk in rural areas.

The layer stacking and averaging can eliminate several atmospheric- or surface distortions and highlighting the most problematic areas in the Katowice area. In this way, constant heat emitters such as city centers and residential areas with little or no vegetation, industrial areas, coal-waste dumps without vegetation and roads can be strengthened. The SUHI risk and $\mathrm{SUHI}_{\text {intensity }}$ images were layer stacked separately and mean values calculated (Fig. 4). It is better to prepare such a layer stacking for the same summer season to avoid distortions due to land-use changes. As in the example of Du et al. (2014) who reported a long-term analysis in Nanjing (China) lasting over 20 years, most of UHIs remained in the central parts of Nanjing and their area and intensity increased remarkably over the past 20 years.

The effects of varying weather conditions on air temperatures can be easily

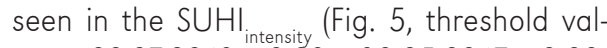
ues: 29.07.2013: 0.23; 30.05.2017: 0.29; 18.08.2017: 0.33; 16.09.2016: 0.34). The local air temperatures were measured between 9:00-10:00 a.m. (IETU Kossutha - same station where air quality data was measured and Muchowiec Airport meteorological station data source: https://ogimet.com) and they were compared with the LST image using mean $3 \times 3$ pixel values of ROI (Region of Interest) over the position of the station. Landsat images were acquired (scene center) between 09:30-09:40 a.m. (Tab.). The extension of the $\mathrm{SUHI}_{\text {intensity }}$ significantly increased in highly built-up areas when the morning surface- and air temperatures were $31-32^{\circ} \mathrm{C}$. The NDVI and NDBI can indicate places such as construction sites and bare soils which are often overheated (during daytime) and are, thus, heat emitters (Fig. 5). Also, Figure 5 well represents how the "green roof" can decrease SUHI effect and how an old structure - Spodek Arena remained as heat emitter. After the construction of the International

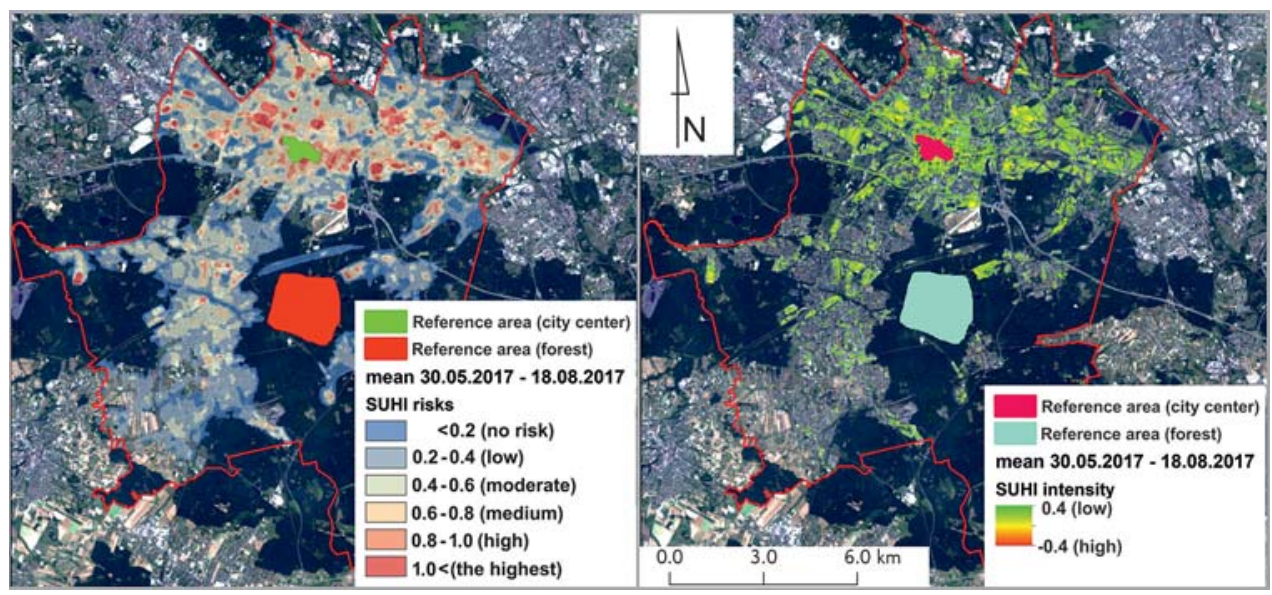

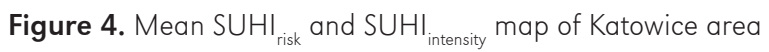



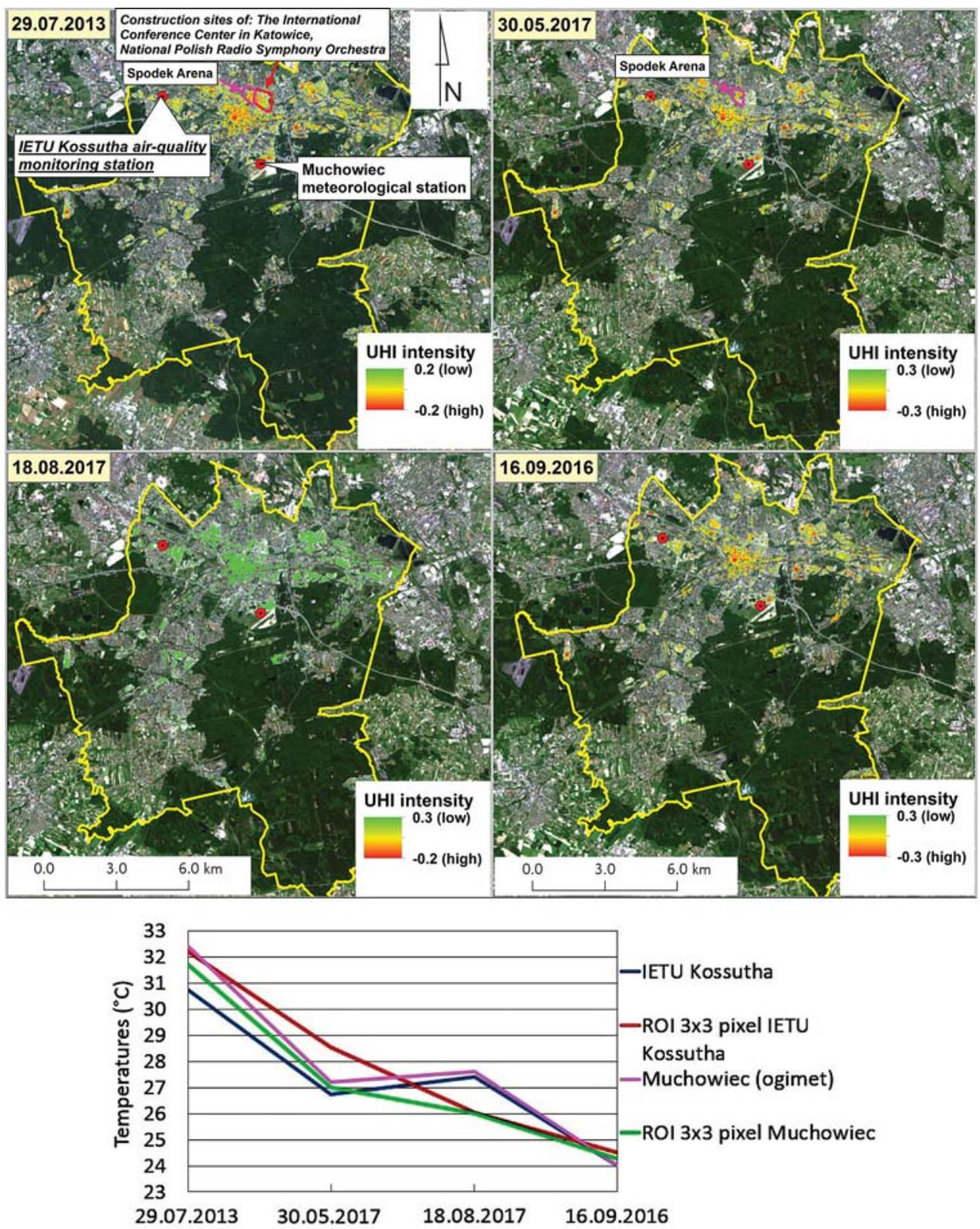

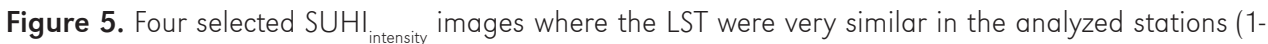
$2^{\circ} \mathrm{C}$ difference)

Conference Center in Katowice has not appeared as a new SUHI close to the city center. The roof of the building complex is covered by grass with aims to create a public green place in a post-industrial area with an integrated system of land slopes and natural diversity of terrain. Such green roofing system is usually applied for energy savings by decreasing the demand for space conditioning and can help in mitigation of urban heat island effect, in the improvement of air pollution, water management, an increase 
of sound insulation, air humidity and its circulation, and ecological preservation (Liu \& Baskaran, 2003; Berardi et al., 2014). Especially in summer, plants shade the substrate, resulting in less sunlight reaching it therefore this decreases both the absorption and the subsequent heat release. Also, green areas collect less sunlight than streets and buildings during the day (Drozd, 2019). The increasing size of such green spaces with lawns and trees can create relatively mild biothermal conditions and it can significantly reduce the SUHI effect even in a housing estate as an example showed by Błażejczyk et al. (2016) in Warsaw. The formation of new SUHI after the construction of a new shopping center is well seen on a SUHI ${ }_{\text {intensity }}$ map (Fig. 6, the calculated threshold values of SUHI intensity $_{\text {for }}$ 23.07.1996: 0.48 and for 09.081999: 0.27). The 3 Stawy Shopping Center built in 1999 is situated close to the city center, between the A4 motorway and Dolina Trzy Stawy.

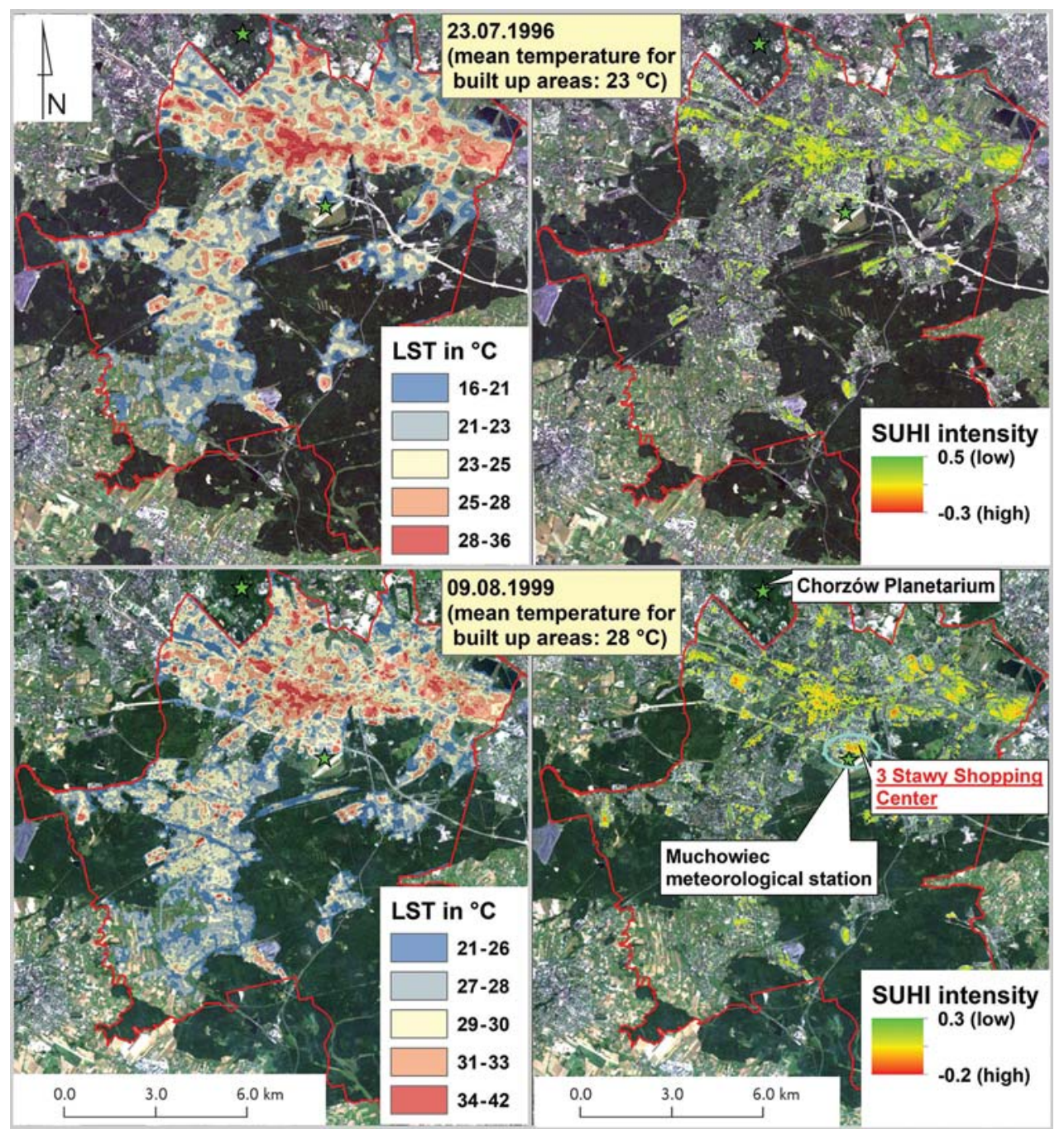

Figure 6. Two SUHI risk and $\mathrm{SUHI}_{\text {intensity }}$ images of Katowice prepared for the introduction of new SUHI formation 
The research is dealing with the localization of SUHI in Katowice conurbation. However, the application of temperature duration curves can help to introduce the AUHI effects i.e. the trend of maximal temperatures detected during summer caused by the different heat emitters (SUHI) within a built-up area. Measuring the AUHI effect is required a long term temperature data from different meteorological stations within a built-up area. The application of daily maximum-temperature duration curves at both Muchowiec (1973-2017) and Chorzów-Planetarium (1994-2016) meteorological stations indicate increasing maximum temperatures with the passage of time at stations (Fig. 7A-D). The Muchowiec data (Fig. 7B) reveal a huge $\left(>25^{\circ} \mathrm{C}\right)$ increase of temperatures between 1992-2007; this is 5\% more than
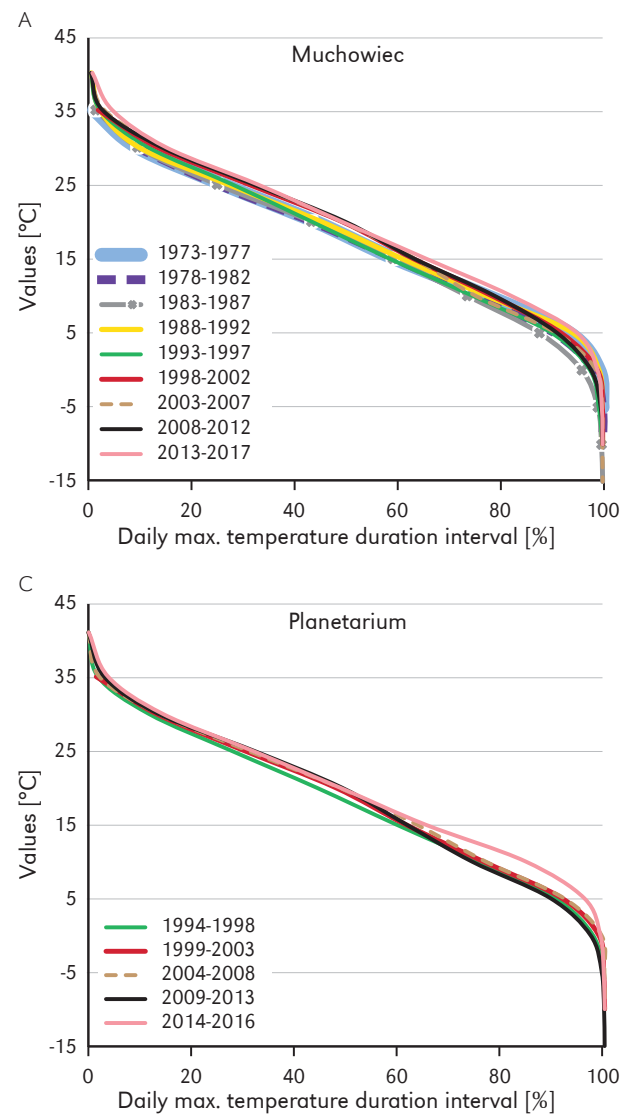

between 1973-1992. In the case of Chorzów-Planetarium, the temperatures with 4\% more times reached and passed the $20^{\circ} \mathrm{C}$ border in 2014-2016 than in 1994-1998 (Fig. 7D). However, this station is located in the city park where the vegetation cover should decrease the effect of $\mathrm{AUHI}$ or SUHI. The duration curves can also be applied to show local changes on the exceedance diagram (Fig. 7D). Comparing the temperature exceedances $>20^{\circ} \mathrm{C}$ from the Muchowiec and Chorzów-Planetarium stations, a small increase (2\%) at Muchowiec is evident between 1999 and 2003. Such rising maximal temperatures can be related to global climate or land-use changes. The climate change in Katowice conurbation is characterized by increases of daily average and maximum temperatures,

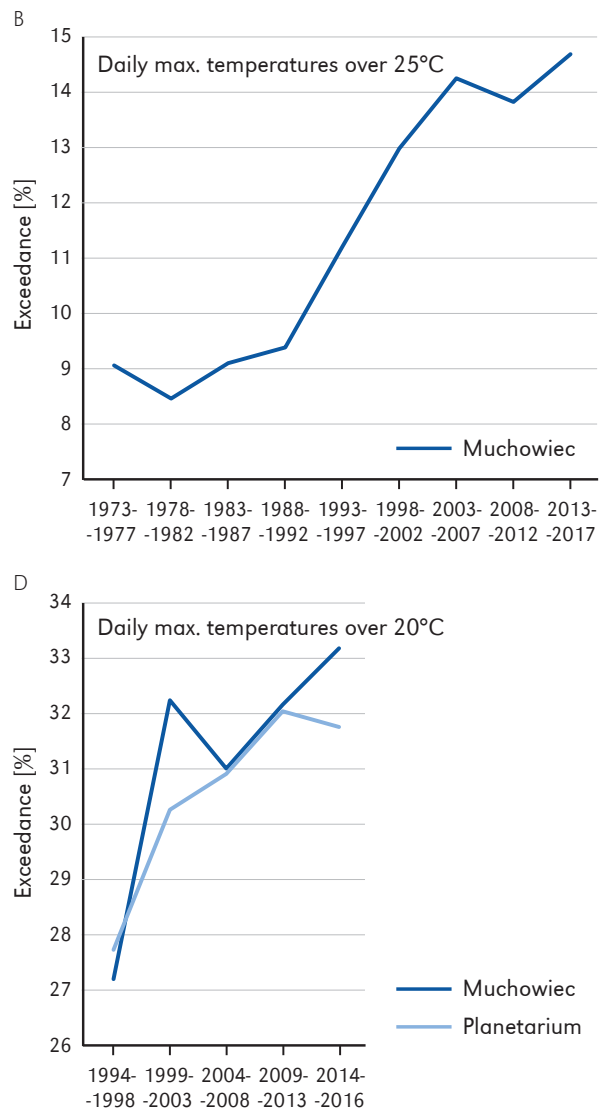

Figure 7. Temperature exceedance duration counted for Muchowiec and Chorzów Planetarium using archived daily maximum-temperature data 
numbers of days with temperatures $>30^{\circ} \mathrm{C}$, numbers and lengths of yearly heatwaves and numbers of days with temperature $>25^{\circ} \mathrm{C}$ without rain and extreme rains events resulting flash flood (Kuchcik, 2017; Fudała et al., 2018; Cenowski et al., 2019). In Poland, over $80 \%$ of nights are characterized by surplus heat in towns, amounting to $2-4^{\circ} \mathrm{C}$, and sporadically to $8^{\circ} \mathrm{C}$ and more (Kłysik \& Fortuniak, 1999). According to Kaplan et al. (2018), global climate change is expected to increase the occurrence of urban heat island effects. Thus, these urban areas may show acute economic-, social-, and environmental impacts adverse to human health. Furthermore, due to increasing numbers of inhabitants resulting from rapid urbanization, cities are more threatened by a higher risk of extreme hightemperature events such as heat waves characterized by higher intensity, higher frequency, and longer duration as a result of the $\mathrm{UHI}$ effect (Weng, 2003; Meehl \& Tebaldi, 2004; Field et al., 2012).

\section{Conclusions}

The SUHI ${ }_{\text {intensity }}$ drastically increased in highly built-up areas when the morning temperatures were $31-32^{\circ} \mathrm{C}$, and the SUHI intensity is greatly influenced by seasonal-weather variations. The localization of $\mathrm{SUHI}_{\text {intensity }}$ using a combination of normalized difference built-up index (NDBI), normalized difference vegetation index (NDVI), and LST were described. Negative values of SUHI indicate potential SUHI (heat emitting risk areas) locations in densely built-up areas, i.e., city centers of the greatest population such as Katowice or Bytom. Therefore the $\mathrm{SUHI}_{\text {intensity }}$ and $\mathrm{SUHI}_{\text {risk }}$ maps confirm the application of remote sensing data in case of land-use changes and detection of SUHI phenomenon in Katowice conurbation. Such $\mathrm{SUHI}_{\text {intensity }}$ and $\mathrm{SUHI}$ risk maps can be helpful in the development of strategies for sustainable management and preservation of urban green to moderate the SUHI environment.

The results indicated well the differences between SUHI (heat emitters like densely built-up areas, construction sites) and $\mathrm{AUHI}$ (represented by temperature measurements). The SUHI can be well localized and reduced by increasing green space in a built-up area i.e. using green roof cover see by International Conference Center in Katowice. However, to reduce the global AUHI effect over that large built-up areas like Katowice conurbation is required more effort. The urban sprawl in the region is visible with newly formed SUHI spots like shopping centers, business parks, housing estates which will increase the $\mathrm{AUHI}$ effect as they emitting additional hot air to the cities' atmosphere.

Using the daily maximum temperatureduration curves well revealed the increasing temperatures in both stations which cannot be visible by the Landsat series. The tendency of increasing maximal temperatures during hot days caused probably by global climate change and urban grow which strengthening the AUHI and SUHI effect within the Katowice conurbation. A good example is showed by the meteorological data from ChorzówPlanetarium (Silesian Park - Park Śląski) where no SUHI thanks for the large vegetation cover is but the maximal temperatures are increasing in the last 20 years. Even that large vegetation cover cannot reduce the AUHI effect. That similar trend was also observed by the Muchowiec meteorological station.

\section{Acknowledgments}

This research was financed by IETU (Instytut Ekologii Terenów Uprzemysłowionych - Institute for Ecology of Industrial Areas) and it was part of a project no. 1/2017/DZM: The development of plans to adapt to climate changes in cities with over 100 thousand inhabitants. The project aimed to assess the sensitivity of the 44 largest Polish cities in the aspect of climate change and to evaluate urban planning adaptation activities.

Editors' note:

Unless otherwise stated, the sources of tables and figures are the authors', on the basis of their own research. 


\section{References}

Abegunde, L., Adedeji, O. (2015). Impact of landuse change on surface temperature in Ibadan, Nigeria. International Journal of Environmental, Chemical, Ecological, Geological and Geophysical Engineering, 9(3), 235-241. https://doi.org/10.5281/zenodo.1099836

Alfraihat, R., Mulugeta, G., Gala, T.S. (2016). Ecological evaluation of urban heat island in Chicago city, USA. Journal of Atmospheric Pollution, 4(1), 23-29. https://doi.org/10.12691/jap-4-1-3

Aslan, N., Koc-San, D. (2016). Analysis of relationship between urban heat island effect and land use/ cover type using Landsat 7 ETM+ and Landsat 8 OLI images. The International Archives of the Photogrammetry, Remote Sensing and Spatial Information Sciences, 41.

Berardi, U., GhaffarianHoseini, AH., GhaffarianHoseini, A. (2014). State-of-the-art analysis of the environmental benefits of green roofs. Applied Energy, 115, 411-428. https://doi.org/10.1016/j.apenergy.2013.10.047

Błażejczyk, K., Kuchcik, M., Dudek, W., Kręcisz, B., Błażejczyk, A., Milewski, P., Szmyd, J., Pałczyński, C. (2016). Urban heat island and bioclimatic comfort in Warsaw. In F. Musco (Ed.), Counteracting urban heat island effects in a global climate change scenario (pp. 305-321). Cham: Springer. https://doi.org/10.1007/978-3-319-10425-6_11

Bokwa, A. (2011). Urban heat island in Kraków, Poland: Interaction between the land use and the land form. In H. Středová, J. Rožnovský, T. Litschmann (Eds.), Mikroklima a mezoklima krajinných struktur a antropogenních prostředí. Skalní mlýn, 2. - 4.2.

Camilloni, I., Barros, V. (1997). On the urban heat island effect dependence on temperature trends. Climatic Change, 37(4), 665-681. https://doi.org/10.1023/A:1005341523032

Cenowski, M., Fudała, J., Strzelecka- Jastrząb, E. (2019). Zagrożenia miejskie wynikające ze zmian klimatu. In J. Gorgoń (Ed.), Obszary miejsko-przemysłowe wobec zmian klimatu na przykładzie miast centralnej części Górnoślq̨sko-Zagłębiowskiej Metropolii (pp. 37-53). Zabrze: Instytut Podstaw Inżynierii Środowiska Polskiej Akademii Nauk.

Chen, Q., Ren, J., Li, Z., Ni, C. (2009). Urban heat island effect research in Chengdu City Based on MODIS Data. In Proceedings of 3rd International Conference on Bioinformatics and Biomedical Engineering (pp. 1-5). ICBBE 2009, Beijing, China, 11-13 June.

Czubaszek, R., Wysocka-Czubaszek, A. (2016). Urban heat island in Białystok. Journal of Ecological Engineering, 17(3), 60-65. https://doi.org/10.12911/22998993/63323

Dong, W., Liu, Z., Zhang, L., Tang, Q., Liao, H., Li, X'en. (2014). Assessing heat health risk for sustainability in Beijing's urban heat island. Sustainability, 6(10), 7334-7357. https://doi.org/10.3390/su6107334

Drozd, W. (2019). Problems and benefits of using green roofs in Poland. IOP Conference Series: Earth and Environmental Science, 214(1), 1-10. IOP Publishing. https://doi.org/10.1088/1755-1315/214/1/012076

Du, L., Zhou, T., Li, M.S., Gong, D.Y. (2014). Urban heat island effects derived from dense Landsat thermal observations in Nanjing, China. IOP Conference Series: Earth and Environmental Science, 17(1). 012162. IOP Publishing.

Fashae, O.A., Adagbasa, E.G., Olusola, A.O., Obateru, R.O. (2020). Land use/land cover change and land surface temperature of Ibadan and environs, Nigeria. Environmental Monitoring and Assessment, 192(2), 109-127. https://doi.org/10.1007/s10661-019-8054-3

Field, C.B., Barros, V., Stocker, T.F., Dahe, Q. (2012). Managing the risks of extreme events and disasters to advance climate change adaptation: Special report of the Intergovernmental Panel on Climate Change. Cambridge: Cambridge University Press. https://doi.org/10.1017/CBO9781139177245

Fortuniak, K. (2003). Miejska wyspa ciepła: podstawy energetyczne, studia eksperymentalne, modele numeryczne i statystyczne. Łódź: Wydawnictwo Uniwersytetu Łódzkiego.

Fudała, J., Nádudvari, Á., Bronder, J., Fudała, M. (2018). Application of satellite images analysis to assess the variability of the surface thermal heat island distribution in urban areas. In E3S Web of Conferences, 28, 01011, EDP Sciences. https://doi.org/10.1051/e3sconf/20182801011 
Gazi, M.A.A., Mondal, I. (2018). Urban heat island and its effect on dweller of Kolkata metropolitan area using geospatial techniques. International Journal Computer Sciences and Engineering, 6(10), 741-753. https://doi.org/10.26438/ijcse/v6i10.741753

Hung, T., Uchihama, D., Ochi, S., Yasuoka, Y. (2006). Assessment with satellite data of the urban heat island effects in Asian mega cities. International Journal of Applied Earth Observation and Geoinformation, 8(1), 34-48. https://doi.org/10.1016/j.jag.2005.05.003

Imhoff, M.L., Zhang, P., Wolfe, R.E., Bounoua, L. (2010). Remote sensing of the urban heat island effect across biomes in the continental USA. Remote Sensing of Environment, 114(3), 504-513. https://doi.org/10.1016/j.rse.2009.10.008

Jiménez-Muñoz, J.C., Sobrino, J.A., Plaza, A., Guanter, L., Moren, J., Martínez, P. (2009). Comparison between fractional vegetation cover retrievals from vegetation indices and spectral mixture analysis: Case study of PROBA/CHRIS data over an agricultural area. Sensors, 9(2), 768-793. https://doi.org/10.3390/s90200768

Kaplan, G., Avdan, U., Avdan, Z.Y. (2018). Urban heat island analysis using the Landsat 8 satellite data: A case study in Skopje, Macedonia. In Multidisciplinary Digital Publishing Institute Proceedings (vol. 2, no. 7, p. 358). https://doi.org/10.3390/ecrs-2-05171

Katsoulis, B.D., Theoharatos, G.A. (1985). Indications of the urban heat island in Athens, Greece. Journal of Climate and Applied Meteorology, 24, 1296-1302. https://doi.org/10.1175/1520-0450(1985)024<1296:IOTUHI>2.0.CO;2

Kim, H.H. (1992). Urban heat island. International Journal of Remote Sensing, 13(12), 2319-2336. https://doi.org/10.1080/01431169208904271

Klejnowski, K., Pastuszka, J.S., Rogula-Kozłowska, W., Talik, E., Krasa, A. (2012). Mass size distribution and chemical composition of the surface layer of summer and winter airborne particles in Zabrze, Poland. Bulletin of Environmental Contamination and Toxicology, 88(2), 255-259. https://doi.org/10.1007/s00128-011-0452-3

Kłysik, K., Fortuniak, K. (1999). Temporal and spatial characteristics of the urban heat island of Łódź, Poland. Atmospheric Environment, 33(24-25), 3885-3895. https://doi.org/10.1016/S1352-2310(99)00131-4

Krzysztofik, R., Runge, J., Spórna, T. (2011). Delimitacja regionu Górnoślasko-Zagłębiowskiej Metropolii "Silesia". Sosnowiec: Wydział Nauk o Ziemi Uniwersytet Śląski.

Kuang, W., Liu, Y., Dou, Y., Chi, W., Chen, G., Gao, C., Yang, T., Liu, J., Zhang, R. (2015). What are hot and what are not in an urban landscape: Quantifying and explaining the land surface temperature pattern in Beijing, China. Landscape Ecology, 30(2), 357-373. https://doi.org/10.1007/s10980-014-0128-6

Kuchcik, M. (2017). Warunki termiczne w Polsce na przełomie XX i XXI wieku i ich wpływ na umieralność (Vol. 263). IGiPZ PAN.

Kuchcik, M., Błażejczyk, K., Milewski, P., Szmyd, J. (2014). Urban climate research in Warsaw: The results of microclimatic network measurements. Geographia Polonica, 87(4), 491-504. https://doi.org/10.7163/GPol.2014.33

Landsberg, H.E. (1981). The urban climate. New York: Academic Press.

Lewińska, J., Bartosik, J., Baścik, J., Czerwieniec, M., Zgud, K. (1982). Wpływ miasta na klimat lokalny (na przykładzie aglomeracji Krakowskiej). Warszawa: Instytut Ksztaltowania Srodowiska.

Liu, K., Baskaran, B. (2003). Thermal performance of green roofs through field evaluation. In Proceedings for the First North American Green Roof Infrastructure Conference, Awards and Trade Show (pp. 1-10).

Liu, L., Zhang, Y. (2011). Urban heat island analysis using the Landsat TM Data and ASTER Data: A case study in Hong Kong. Remote Sensing, 3, 1535-1552. https://doi.org/10.3390/rs3071535

Lu, Y., Feng, P., Shen, C., Sun, J. (2009). Urban heat island in summer of Nanjing based on TM Data. In Proceedings of 2009 Joint Urban Remote Sensing Event (pp. 1-5). IEEE. https://doi.org/10.1109/URS.2009.5137628 
Majkowska, A., Kolendowicz, L., Półrolniczak, M., Hauke, J., Czernecki, B. (2017). The urban heat island in the city of Poznań as derived from Landsat 5 TM. Theoretical and Applied Climatology, 128, 769-783. https://doi.org/10.1007/s00704-016-1737-6

Martin, P., Baudouin, Y., Gachon, P. (2015). An alternative method to characterize the surface urban heat island. International Journal of Biometeorology, 59(7), 849-861. https://doi.org/10.1007/s00484-014-0902-9

Meehl, G.A., Tebaldi, C. (2004). More intense, more frequent, and longer lasting heat waves in the 21st century. Science, 305(5686), 994-997. https://doi.org/10.1126/science.1098704

Oke, T.R. (1982). The energetic basis of the urban heat-island. Quarterly Journal of the Royal Meteorological Society, 108(455), 1-24. https://doi.org/10.1002/qj.49710845502

Oke, T.R. (1988). The urban energy balance. Progress in Physical Geography: Earth and Environment, 12(4), 471-508. https://doi.org/10.1177/030913338801200401

Oleson, K.W., Monaghan, A., Wilhelmi, O., Barlage, M., Brunsell, N., Feddema, J., Hu, L., Steinhoff, D.F. (2005). Interactions between urbanization, heat stress, and climate change. Climatic Change, 129(3-4), 525-541. https://doi.org/10.1007/s10584-013-0936-8

Qin, Z-H., Zhang, M-H., Karnieli, A., Berliner, P. (2001). Mono-window algorithm for retrieving land surface temperature from Landsat TM6 data. Acta Geographica Sinica, 56(4), 456-466. https://doi.org/10.11821/xb200104009

Rajagopalan, P., Lim, K.C., Jamei, E. (2014). Urban heat island and wind flow characteristics of a tropical city. Solar Energy, 107, 159-170. https://doi.org/10.1016/j.solener.2014.05.042

Rogula-Kozłowska, W., Błaszczak, B., Klejnowski, K. (2011). Concentrations of PM2.5, PM2.5-10 and PM-related elements at two heights in an urban background area in Zabrze (Poland). Archives of Environmental Protection, 37(2), 31-47. https://doi.org/10.1007/s10661-009-1138-8

Spórna, T., Kantor-Pietraga, I., Krzysztofik, R. (2016). Trajectories of depopulation and urban shrinkage in the Katowice Conurbation, Poland. Espace Populations Societes, 2015/3-2016/1. https://doi.org/10.4000/eps.6102

Streutker, D.R. (2002). A remote sensing study of the urban heat island of Houston, Texas. International Journal of Remote Sensing, 23(13), 2595-2608. https://doi.org/10.1080/01431160110115023

Suresh, S., Suresh, A.V., Mani, K. (2016). Estimation of land surface temperature of high range mountain landscape of Devikulam Taluk using Landsat 8 data. IJRET: International Journal of Research in Engineering and Technology, 5(1), 92-96. https://doi.org/10.15623/ijret.2016.0501017

Szymanowski, M. (2004). Miejska wyspa ciepła we Wrocławiu. Acta Universitatis Wratislaviensis, 2690, Studia Geograficzne, 77, Wrocław: Wydawnictwo Uniwersytetu Wrocławskiego.

Tarawally, M., Xu, W., Hou, W., Mushore, T.D. (2018). Comparative analysis of responses of land surface temperature to long-term land use/cover changes between a coastal and inland city: A case of Freetown and Bo Town in Sierra Leone. Remote Sensing 10(1), 112-130.

https://doi.org/10.3390/rs10010112

Tkocz, M. (2001). Restrukturyzacja przemysłu regionu tradycyjnego. Katowice: Wydawnictwo Uniwersytetu Śląskiego.

U.S. Environmental Protection Agency (U.S. EPA). (2014a). Reducing urban heat islands: Compendium of strategies. Retrieved from https://www.epa.gov/heatislands/heat-island-compendium

U.S. Environmental Protection Agency (U.S. EPA). (2014b). Climate change indicators in the United States, 2014. Third edition. EPA 430-R-14-004.

Wang, W., Zheng, Z., Karl, T.R. (1990). Urban heat islands in China. Geophysical Research Letters, 17(13), 2377-2380. https://doi.org/10.1029/gl017i013p02377

Weng, Q. (2003). Fractal analysis of satellite-detected urban heat island effect. Photogrammetric Engineering \& Remote Sensing, 69(5), 555-566. https://doi.org/10.14358/pers.69.5.555 
Weng, Q.H. (2012). Remote sensing of impervious surfaces in the urban areas: Requirements, methods, and trends. Remote Sensing of Environment, 117, 34-49. https://doi.org/10.1016/j.rse.2011.02.030

Weng, Q., Lu, D., Schubring, J. (2004). Estimation of land surface temperature-vegetation abundance relationship for urban heat island studies. Remote Sensing of Environment, 89(4), 467-483. https://doi.org/10.1016/j.rse.2003.11.005

Wilk, S. (2015). Urban Heat Island in Lodz. ICUC9 - 9th International Conference on Urban Climate jointly with 12th Symposium on the Urban Environment. Toulouse, France, July 20-24, 2015.

Yang, L., Qian, F., Song, De-X., Zheng, Ke-J. (2016). Research on urban heat-island effect. Procedia Engineering, 169, 11-18. https://doi.org/10.1016/j.proeng.2016.10.002

Zaciera, M., Kurek, J., Dzwonek, L., Feist, B., Jędrzejczak, A. (2012). Seasonal variability of PAHs and nitroPAHs concentrations in total suspended particulate matter in ambient air of cities of Silesian Voivodeship. Environment Protection Engineering, 38(1), 45-50.

Zaeemdar, S., Baycan, T. (2017). Analysis of the relationship between urban heat island and land cover in Istanbul through Landsat 8 OLI. Journal of Earth Science and Climatic Change, 8(11), 423-432. https://doi.org/10.4172/2157-7617.1000423 